\title{
Enteric Diarrhoeal disease in sheep caused by Campylobacter infection in Alexandria Governorate
}

\author{
Ola .A. Basha and F. A. El-Shaboury \\ Animal Health Research Institute \\ Alexandria branch . Bacteriology Dept.
}

\begin{abstract}
Summary
The incidence of Campylobacter jejuni and Campylobacter coli harbouring the intestine of sheep with diarrhea was studied. A total number of 100 rectal swab samples were collected from sheep suffering from diarrhea at Alexandria governorate animal inclosures . The samples were examined bacteriologically. The bacteriological examination revealed the isolation of Campylobacter jejuni from $12(12 \%)$ out of 100 examined sheep, while Campylobacter coli could be isolated from 9 cases of diarrheic sheep examined .

Moreover, Campylobacter isolated in this study were tested for susceptibility of 10 antibiotics . None of the isolates were resistant to Chloramphenicol and high percentages of isolates were resistant to Tetracycline, Penicillin and Sulphamethoxzole. These results indicate that Campylobacter colonization in the intestine is very common in sheep and the bacteria play a role in aggravation of diarrhea process . The public health importance of Campylobacter jejuni and Campylobacter coli were discussed .
\end{abstract}

\section{Introduction}

Diarrhoea is the most common symptom of illness in lambs, which can be caused by many organisms, and more than one causative agent can be present in the one animal like Salmonella , E-coli , Viruses such as Rotavirus and Campylobacter which can also cause this problem ( Radostits et al, . 2000 ) . Campylobacter species are now recognized as one of the most important causes of enteric diarrhoeal disease in domestic animals and humans throughout the world ( Atabay and Corry , 1997) . hence, Campylobacter enteritis constitutes a zoonoses of major concern in puplic health and indeed, has been shown to be a greater problem than salmonellosis in several countries (Stanley et al., 1998). Campylobacter is one of the most important foodborn microorganisms leading to gastroenteritis in human. These human cases are most likely associated with handling or consumption of undercooked meat products ( Oosterom et al .,1984) .

The source of infection for humans in developed countries is though to be the massive reservoir of Campylobacter jejuni and to a lesser extent Campylobacter coli in the animal population . It is assumed that man may be infected by direct contact with diseased animals suffering from Campylobacter diarrhoea or by consumption of food or water contaminated by secretion or excretion of diseased animals ( Acha and Szyfers . 1991, Shakespeare , 2002 and Harmut et al ., 2003 ). Campylobacter is a Gram- negative cylender, curved, and motile rod . It is a microaerophilic organism, as it requires a reduced levels of oxygen for growth. It is relatively fragile, and sensitive to environmental stresses such as $20 \%$ oxygen, drying, heating, disinfectants and acidic conditions . Because of its microaerophilic characteristics, the organism requires $5 \%$ oxygen and $10 \%$ carbon dioxide for optimal growth conditions (Betty et al. , 1998 ). It is evident that Campylobacter jejuni 
and Campylobacter coli are responsible factor of diarrhea in sheep ( Diker , 1987 ; Terzolo , 1988 and Khalil et al ., 1993 ) .

Increasing antimicrobial resistance Campylobacter infection cases is a recognized problem,( Saenz et al ., 2000 and Jensen and Aarestrup , 2001 ). However, Gur et al . (1989) stated that quinolone antibiotics were very active against Campylobacter species and showed that there was no any marked difference between the susceptibility patterns of C. jejuni and C.coli .

The present study was designed to investigate the presence of Campylobacter infection in sheep at Alexandria governorate animal inclosures . Moreover, due to the public health hazard of antibiotic resistant for Campylobacter, antibiotic sensitivity patterns of Campylobacter Jejuni and Campylobacter coli were evaluated .

\section{Material and Methods}

\section{Collection of samples :}

Sterile rectal swab samples were collected from 100 diarrheic sheep of different ages and sex suffering from diarrhea, raised in small groups at Alexandria governorate .

\section{Bacteriological examination :}

Rectal swab samples were inoculated into sterile tube containing brucella broth (Retting, 1979) to preserve the viability of the organism during transportation to the laboratory. The samples were examined for Campylobacter jejuni and Campylobacter Coli by streaking on Skirrow medium (Skirrow , 1977 )containing 5-7 \% horse blood and Campylobacter selective supplement (Oxoid ) . The plates were incubated at $42 \mathrm{C}$ for 48 hours in an atmosphere of $5 \%$ oxygen , $10 \%$ carbon dioxide and $85 \%$ nitrogen in standard anaerobic jars. The bacterial isolates were purified and identified by using colonial , morphological and biochemical characteristics ( Koneman et al . 1988 and

Quinn et al . 2002 ).

\section{In - vetro antibiotic sensitivity test :}

Different types of antibacterial sensitivity discs were used in the sensitivity tests to determine the sensitivity and resistance of different isolated strains of Campylobacter jejuni and Campylobacter coli. The antibiotic discs were obtained from Oxoid. The technique was carried out using disc diffusion method according to Bopp et al . (1985).Three colonies of Campylobacter organisms were inoculated into tubes containing $5 \mathrm{ml}$ Muller Hinton broth ( Oxoid ), then incubated for eight hours under reduced oxygen tension at $37^{\circ} \mathrm{C}$ until the turbidity exceeded that of the standard McFarland 0.5 barium sulphate tube $(0.5 \mathrm{ml}$ of $1.175 \%$ barium chloride hydrate to 99 $\mathrm{ml}$ of $1 \%$ sulphuric acid ). The turbidity was adjusted to match that of the McFarland 0.5 barium sulphate standard tube by adding sterile saline solution. The suspension was then inoculated evenly on $150 \mathrm{~mm}$ Muller - Hinton agar plates supplemented with $5 \%$ defebrinated sheep blood . Antibiotic discs were placed on the surface of agar plate in a radial pattern with the lowest concentration toward the center. The plates were incubated for 72 hours at $37{ }^{\circ} \mathrm{C}$ under the microaerophilic conditions and the inhibitory zone diameters were measured . 


\section{Results}

Incidence of C. jejuni and C. coli in rectal swab samples collected from diarrheic sheep:

Isolates of Campylobacter jejuni were recovered from 12 ( $12 \%$ ) out of 100 rectal swab fecal samples examined while Campylobacter coli was recovered in 9 ( $9 \%$ )of diarrheic sheep .

Totally C. jejuni and C. coli could be isolated from 21 out of 100 sheep examined Table (1) . The biochemical characteristics of Campylobacter isolates are illustrated in Table (2).

In - Vitro antimicrobial sensitivity

As shown in Table (3), C. jejuni isolated were sensitive to Chloramphenicol ( $100 \%$ ) followed by Neomycin and Gentamycin ( $80 \%$ ), while $60 \%$ only for Ampicillin . On the other hand, all isolates of C. jejuni were resistant to Tetracyclin ( $100 \%$ ) and $80 \%$ of isolates were resistant to Erythromycin, Sulphamethoxazole and Pencillin .

As shown in table ( 4 ), C. coli isolated from sheep rectal swab samples were sensitive to Ampicillin and Neomycin ( $100 \%$ ) followed by Chloramphenicol ( $80 \%$ ) but they showed high resistance to Penicillin , Tetracyclin and Naladixic acid .

\section{Discussion}

Campylobacter species are microaerobic inhabitant of the gastrointestinal tract of various animals including sheep ( Betty et al . 1998 ). It have been recognized as a cause of diarrhea in sheep ( Radostitis et al . 2000 ). In this study, rectal swab samples were collected from sheep with diarrhea and used for isolation of Campylobacter jejuni and Campylobacter coli . As shown in table 1 Campylobacter jejuni was isolated from examined rectal swab sheep samples at a percentage of $12 \%$.This bacteria was isolated from sheep faeces by many various studies ( Turkoson et al . 1988 and Adesiyun et al . 1992 ). Nearly similar percentage was recorded by Rosef et al . ( 1983 ) who isolated $8.1 \%$. Higher recovery rates were recorded by Manser and Dalziel ( 1985 ) and Adesiyun et al . ( 1992 ) who isolated 22 and $17.9 \%$ respectively .

On the other hand, low rate of $2 \%$ was recorded by Turkoson et al . (1988) . These differences in isolation rates may be attributed to sample collection in different seasons as high temperature in summer months, while lower recovery rates occurred during winter and spring and this was reported by Hanninen et al . ( 2000 ). The result illustrated in table 1 showed that Campylobacter coli was isolated from examined rectal swab sheep samples at percentage of $9 \%$. Nearly similar results were recorded by Terzolo ( 1988 ) and Kakkar and Dogra ( 1990 ), and lower result was reported by Rosef et al . ( 1983 ) but higher result was recorded by Giacoboni et al.(1993 )

The rate of isolation for Campylobacter jejuni was higher than Campylobacter coli in rectal swab samples of sheep . Table ( 1 ). This support the observation of Rosef et al ., ( 1983 ) and Busato et al.(1999) who reported that Campylobacter coli is less frequently involved in animal than Campylobacter jejuni . However, the epidemiological features of both are similar and sometimes not further differentiated in literature ( Busato et al . 1999) .

Campylobacteriosis is acute or chronic infection of humans and animals, Transmission from animals to human has been known for Campylobacter jejuni and Campylobacter coli . The infection in man is manifested generally by acute enteritis, abdominal pain, diarrhea in most cases with stool 
contain blood, pus or mucous, fever up to $40{ }^{\circ} \mathrm{C}$ and in few cases vomiting. Abdominal symptoms may lead to laparotomy or appendectomy ( Acha and Szyfers , 1991 and Hartmut et al . 2003 ) .

In- vetro antibiotic sensitivity test was done against isolated strains of Campylobacter using a panel of 10 antibiotics ( Table ,3 and 4 ). The most effective antibiotics for all isolates of Campylobacter jejuni and Campylobacter coli were Chloramphenicol . This support the data reported by Diker et al . ( 1990 ) The isolates of Campylobacter species at this study were resistant to Tetracycline Penicillin and Sulphamethoxazole. These findings agree with that recorded by Erdger and Diker ( 1995 ).

In conclusion, due to the presence of Campylobacter in the small intestine of sheep represent a public health hazard . Moreover, because of multidrug resistance among Campylobacters hygienic measures should be undertaken such as cleaning and disinfection of animal houses, avoidance of improper use of antibiotics, hygienic disposal of animal excreta and proper cooking and hygienic handling of meat befor consumption .

Table ( 1 ) : Incidence of C . jejuni and C.coli in rectal swab samples collected from diarrheic sheep.

\begin{tabular}{|l|l|c|c|c|}
\hline \multirow{2}{*}{ No . of sheep } & \multicolumn{2}{|c|}{ C. jejuni } & \multicolumn{2}{c|}{ C . coli } \\
\cline { 2 - 5 } examined & $\begin{array}{l}\text { No. of } \\
\text { isolates }\end{array}$ & $\%$ & $\begin{array}{c}\text { No . of } \\
\text { isolates }\end{array}$ \\
\hline 100 & 12 & 12 & 9 & 9 \\
\hline
\end{tabular}


Table ( 2 ) : Biochemical reactions of Campylobacter jejuni and Campylobacter coli isolated from sheep suffering from diarrhea .

\begin{tabular}{|c|c|c|}
\hline Test & C. jejuni & C . coli \\
\hline Catalase test & $+\mathrm{ve}$ & +ve \\
\hline Oxidase test & $+\mathrm{ve}$ & +ve \\
\hline $\mathrm{H} 2 \mathrm{~S}$ on lead acetate & $+\mathrm{ve}$ & $+\mathrm{ve}$ \\
\hline $\mathrm{H} 2 \mathrm{~S}$ on $\mathrm{T} \mathrm{S} \mathrm{I}$ & -ve & -ve \\
\hline Nitrate reduction & $+\mathrm{ve}$ & $+\mathrm{ve}$ \\
\hline Hippurate hydrolysis & +ve & -ve \\
\hline Glycin ( $1 \%$ )tolerance test & $+\mathrm{ve}$ & +ve \\
\hline Sodium chloride $(3.5 \%)$ tolerance test & -ve & +ve \\
\hline Growth at $25^{\circ} \mathrm{C}$ & -ve & -ve \\
\hline Growth at $37^{\circ} \mathrm{C}$ & $+\mathrm{ve}$ & $+\mathrm{ve}$ \\
\hline Growth at $42^{\circ} \mathrm{C}$ & $+\mathrm{ve}$ & +ve \\
\hline
\end{tabular}


Table (3) : Antimicrobial sensitivity of Campylobacter jejuni isolated from sheep $(n=5)$

\begin{tabular}{|c|c|c|c|c|c|c|}
\hline \multirow{3}{*}{ Antimicrobial agents } & \multicolumn{6}{|c|}{ Degree of sensitivity } \\
\hline & \multicolumn{2}{|c|}{ Sensitive } & \multicolumn{2}{|c|}{ Moderate } & \multicolumn{2}{|c|}{ Resistant } \\
\hline & No & $\%$ & No & $\%$ & No & $\%$ \\
\hline Neomycin $\mathrm{N} 3 \mathrm{O}$ & 4 & 80 & 1 & 20 & 0 & 0 \\
\hline Gentamycin GM10 & 4 & 80 & 1 & 20 & 0 & 0 \\
\hline Ampicillin AMP10 & 3 & 60 & 2 & 40 & 0 & 0 \\
\hline Stryptomycin S10 & 0 & 0 & 3 & 60 & 2 & 40 \\
\hline Erythromycin E15 & 0 & 0 & 1 & 20 & 4 & 80 \\
\hline Chloramphenicol C30 & 5 & 100 & 0 & 0 & 0 & 0 \\
\hline Naladixic Acid NA30 & 1 & 20 & 1 & 20 & 3 & 60 \\
\hline Sulphamethoxazole SX T25 & 0 & 0 & 1 & 20 & 4 & 80 \\
\hline Penicillin ( $10 \mathrm{I} \mathrm{U}$ ) & 0 & 0 & 1 & 20 & 4 & 80 \\
\hline Tetracyclin T30 & 0 & 0 & 0 & 0 & 5 & 100 \\
\hline
\end{tabular}


Table (4) : Antimicrobial sensitivity of Campylobacter coli isolated from sheep $(\mathrm{n}=5)$

\begin{tabular}{|c|c|c|c|c|c|c|}
\hline \multirow{3}{*}{ Antimicrobial agents } & \multicolumn{6}{|c|}{ Degree of sensitivity } \\
\hline & \multicolumn{2}{|c|}{ Sensitive } & \multicolumn{2}{|c|}{ Moderate } & \multicolumn{2}{|c|}{ Resistant } \\
\hline & No & $\%$ & No & $\%$ & No & $\%$ \\
\hline Neomycin $\mathrm{N} 3 \mathrm{O}$ & 5 & 100 & 0 & 0 & 0 & 0 \\
\hline Gentamycin GM10 & 3 & 60 & 2 & 40 & 0 & 0 \\
\hline Ampicillin AMP10 & 5 & 100 & 0 & 0 & 0 & 0 \\
\hline Stryptomycin S10 & 1 & 20 & 3 & 60 & 1 & 20 \\
\hline Erythromycin E15 & 1 & 20 & 0 & 0 & 4 & 80 \\
\hline Chloramphenicol C30 & 4 & 80 & 1 & 20 & 0 & 0 \\
\hline Naladixic Acid NA30 & 1 & 20 & 0 & 0 & 4 & 80 \\
\hline Sulphamethoxazole SX T25 & 3 & 60 & 2 & 40 & 0 & 0 \\
\hline Penicillin ( 10 I U ) & 0 & 0 & 0 & 0 & 5 & 100 \\
\hline Tetracyclin $\mathrm{T} 30$ & 0 & 0 & 1 & 20 & 4 & 80 \\
\hline
\end{tabular}




\section{Refrences}

Acha , P. N. and Szyfers, B. (1991) :

Zoonoses and Communicable Diseases Common to Man and Animals . $2^{\text {nd }}$ Ed . Pan American Health Organization, Washington D. C.

Adesiyun , A. A. ; Kaminojolo, J. S. ; Loregnard, R. and Kitson , P. W. ( 1992 ) :

Campylobacter infection in calves, piglets, lambs and kids in Trenedad . Br. Vet. J., 148

(6):547-556 .

Atabay , H. I. and Corry, J. E. (1997) :

The prevalence of Campylobacters and Arcobacters in broiler chickens . J. App. Miicrobiol. , 83(5):619-626 .

Betty, A. ; Dniel , F. and Alice, S. W. (1998):

Bailey and scott's Diagnostic microbiology . $10^{\text {th }}$ Ed., Mosby .

Bopp , F. L. Bikness, K. A. ; Washsmuth, I. K. and Barrett , T. J. (1985):

In vetro antimicrobial susceptibility, plasmid analysis and serology of epidemic

Campylobacter jejuni . J. Clin. Microbiol ., 21 (1) : 4-7 .

Busato, A. ; Hofer, D.; Lentze, T. ; Gaillard, C. and Burnens , A. (1999) :

Prevalence and infection risk of zoonotic enteropathogenic bacteria in swiss cow - calf

farms. Vet. Microbiol ., 69: 251-263.

Diker, K. S (1987):

Isolation of Campylobacter species from various animals and evaluation of zoonotic species Microbiol . Bull ., 21(4):957 - 962 .

Diker, K. S. Diker, S. and Ozlem , M. B. (1990)

Bovine diarrhea associated with Campylobacter hyointestinalis . Zentralbl Veterinarmed, B, Mar . ; 37 (2) : 158-160 .

Erdger, J. and Diker, K. S. (1995) :

Multiple antibiotic resistance in poultry isolates of Campylobacter . Veterinar Faku Itesi Dergisi, Ankara universitesi, Ankara, Turkey .

Giacoboni , G. L. ; Itoh , K. ; Hirayama K.; Takahashi, E . and Mitsuoka , T. (1993) : Comparison of faecal Campylobacter in calves and cattle of different ages and areas in Japan . J. vet . Med . sci ., 55 (4): 555 - 559 .

Gur , D. ; Harscelik , G., Akyon , Y. ; Akalin , H. E. and Diker , S. (1989) :

In vetro susceptibility of Campylobacter coli to quinolone antibiotics . Mikrobiyol. Bul. , 23 (3) : 185-189 . 
Hanninen , M. L. ; perk, O. Makela , P. ; pitkala , A. and Rautelin , H. (2000) :

A three year study of Campylobacter jejuni genotypes in humans with domestically acquired infections and in chicken samples from the Helsinki area . J. clin . Microbiol., 38 (5) :

1998-2000.

Hartmut , K. ; Albert , W. ; Max , A., Burkhard , E. ; Henry , D. ; HansGerd, S. ;

Werner, S. ; Alexander, V. and Horst , Z ., ( 2003 ) :

Zoonoses, Infectious Diseases Transmissible from Animals to Humans . $3^{\text {rd }}$ Ed. American

Society for Mirobiology, Washington D. C.

Jensen , L. B. and Aarestrup , F. M. (2001) :

Macrolid resistance in Campylobacter coli of animals origin in Denmark . Antimicrob . agents chemother ., $45: 371-372$.

Kakkar, M . and Dogra , S. C. (1990) :

Prevalence of Campylobacter infection in animals and children in Haryana, India .

J . Diarrhoeal Dis . Res. , 8 ( 1-2 ) 34-36 .

Khalil , k.; Lindblom , G. B. ; Mazhar , k. ; Sjogren, E . and Kaijser, B. (1993) :

Frequency and enterotoxicity of Campylobacter jejuni and Campylibacter coli in domestic animals in Pakistan as compared to Sweden .J. Trop. Med. Hyg., 96(1) : 35-40 .

Koneman , E. W. ; Allen , S. D. ; Dowell, V. R. ;Janda , W. M. ; Sommers, H. M. and Winn, W. C. W. C. (1988) :

Colour Atlas and Textbook of Diagnostic Microbiology . $3^{\text {rd }}$ Ed. T. B. Lippencott, NewYork, London .

Manser, P. A. and Dalziel , R. W. ( 1985 ) :

A survey of Campylobacter in animals . J. Hyg ., 95 (1) : 15-21 .

Oostrom , J. ; Uyl, C. H. Den ; Banfter, J. R. J. and Huisman , J. (1984) :

Epidemiological investigations on Campylobacter jejuni in households with a primary

infection. J. Hyg. Camb . 92 325-332.

Quinin , P. T. ; Markey , B. K. ; Carter , M. E. ; Donnelly , W. J. and Leonard , F. C. (2002) :

Veterinary Microbiology and Microbial Diseases . Blackwell science L T D .

Radostits , O. M. ; Gay , C. C. ; Blood , D. C. ; Hinchcliff, K. W. and Arundel , J. H. (2000):

Diseases caused by bacteria , P. 967. In veterinary medicine , $9^{\text {th }}$ E.d. The W.B. sunders Co., Philadelphia .

Retting, P. J. (1979) :

Campylobacter infections in human being J. Ped., 94 (6) : 855-864 . 
Rosef , O ; Gondrosen , B. ; Kapperud , G and Underdal , B. (1983) :

Isolation and characterization of Campylobacter jejuni and Campylobacter coli from domestic and wild mammals in Norway . Appl. Envirnm. Microbiol. , 46 (4) : 855-859 .

Saenz, Y.; Zarazoga , M.; Lantero , M. ; Jose Gastanares F ; Baquero, M. and Torres, C. (2000) :

Antibiotic resistance in Campylobacter strains isolated from animals, foods, and humans in spain in 1997-1998. Antimicrob. Agents Chemother . 44 : 267-271 .

Shakespeare, M. (2002) :

Zoonoses . Pharmaceutical Press . NewYork, pp 248-250 .

Skirrow , M.B. (1977) :

Campylobacter enteritis . "A new " disease . Br . Med . J. ; 2: 9-11 .

Stanley , K . N. ; Wallace , J. S. ; Currie , J. E. ; Diggle , P. J. and Jones , K . (1998):

The seasonal variation of thermophilic Campylobacter in beef cattle, dairy cattle and calves J. Appl. Microbiol ., 85 (3) : 472-480 .

Terzolo , H. R. (1988) : Identification of Campylobacter from bovine and ovine and ovine feces . Rev. Argent . Microbiol ., 20 (2) : 53-68.

Turkson , P. K. ; Lindquist , K. T. and Kapperude , G. (1988) :

Isolation of Campylobacter species and Yarsinia enterocolitica from domestic animals and human patients in Kenya . APMIS , 96(2) :141-146.

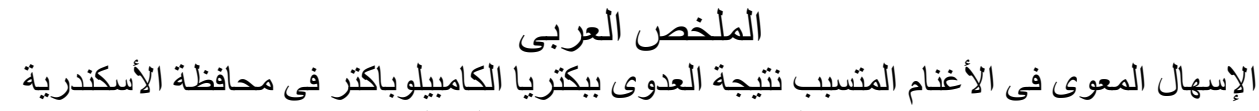

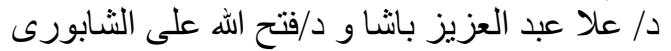

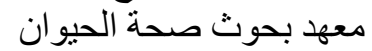

$$
\begin{aligned}
& \text { فرع الأسكندرية - قسم البكتريولوجى } \\
& \text { إثتملت الدر اسة على فحص عدد . . } 1 \text { مسحة شرجية من الأغنام المصابة بالإسهال المعوى لدر اسة مدى الإصابة بعدوى } \\
& \text { ميكروب الكامبيلوباكتر ـ و قد أسفر الفحص البكتريولوجى عن عزل ميكروب الكامبيلوباكتر جوجينى من r ا حيو ان بينما } \\
& \text { تم عزل بكتريا الكامبيلوباكتر كو لاى من } 9 \text { حيو انات مصابة فقط ـ ودلت در اسة تأثير المضادات الحيوية على معزو لات } \\
& \text { الكامبيلوباكتر الجوجينى و الكو لاى أن أفضلها فاعلية كان الكتور امفنيكول يليه النيومايسين و الأمبيسيلين و الجنتاميسين . } \\
& \text { بينما كانت معظم المعزو لات مقاومة للتتر اسيكلين و البنسلين و السلفاميزوكسازول ـو تتلخص هذه الدراسة على أن } \\
& \text { الكامبيلوباكتر تلعب دورا فى الإصابة بالإسهال المعوى فى الأغنام ـ هذا و قد تم مناقتنة الأهميه الصحية العامة لميكروبات } \\
& \text { الكامبيلو باكتر المعزولة و طرق الوقاية منهما . }
\end{aligned}
$$


